Iraq J Pharm

Vol. 15, No.1, 2018

\title{
Histological and Histochemical Changes Induced by Human Chorionic Gonadotropin on Prostate of Adult albino Rats
}

\author{
Waleed H. Kasim, Maha A. Al-Sammak \\ University of Ninevah, College of Medicine, Department of Anatomy
}

$\frac{\text { Received }}{25.5 .2014} \quad \frac{\text { Accepted }}{20.9 .2017}$

\begin{abstract}
Aims of the study: To evaluate the histological and histochemical changes induced by human chorionic gonadotropin (hCG) on the adult prostate and to correlate the changes with the levels of testosterone.
\end{abstract}

Materials and Methods: eighty adult male albino rats were divided into 4 groups; 3 treated and 1 control. The treated groups were received 10,50 or $100 \mathrm{IU} / \mathrm{kg} \mathrm{BW}$ of hCG, while the controls received normal saline. The doses were given twice weekly for 3 months via subcutaneous injections. Subsequently, on day 1, 30, 60 and 90 post therapy, blood samples and the prostate glands were obtained for evaluation.

Results: All the doses of hCG caused accumulation of secretory products within the prostate, which resulted in dilatation of the acinar lumens, reduction of the mucosal folds, and non dose dependent diminution in height of the lining epithelial cells. Moreover, foci of hyperplasic cells were observed in the prostate. The therapy increased the collagen fibers of the gland. The general distribution of the Periodic Acid-Sciff (PAS) +ve material was not altered. Most of these changes were reversible within 3 months.

Conclusions: Treatment with hCG causes accumulation of secretory products within the prostate and in turn affects the structure of the prostate.

Keywords: structural; hyperplasia; histochemical; prostate.

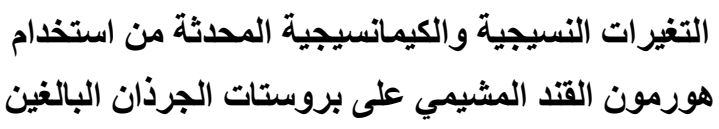

الخلاصة

الهدف: نم تصميم هذه الدراسة لغرض تحديد التغيرات النسيجية والكيميانسيجية الناجمة عن استخدام موجه القند

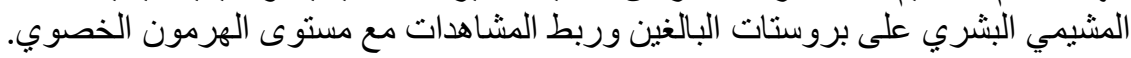

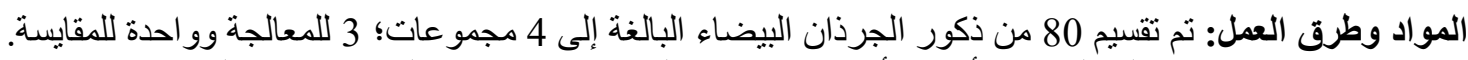

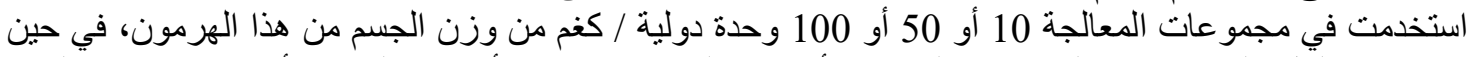

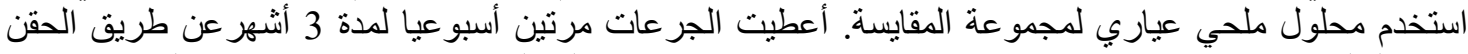

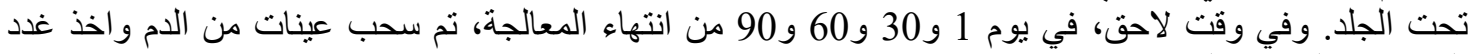

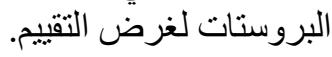

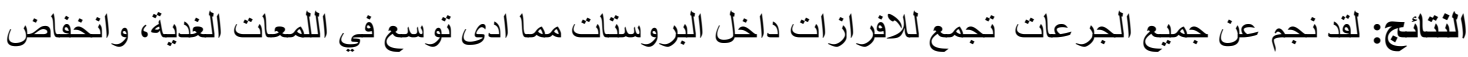

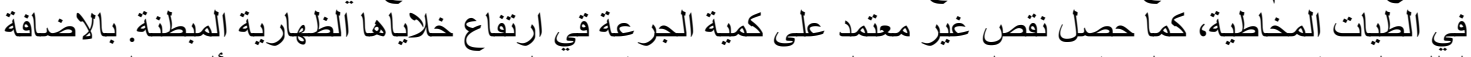
لذللك، لوحظ وجود بؤر لفرط تنسج الخلايا في البروستات. وقد اظهرت النتائج وجود زيادة في الألياف الكو لاجينية 


$$
\begin{aligned}
& \text { لهذه الغذة. بينما لم يحصل اي تغيير في التوزيع العام للمو اد ذات الفعالية الموجبة لصبغة PAS. كما و اثتبت الدراسة } \\
& \text { قابلية عكوسية معظم هذه التغيير ات خلاّل ثلاثة الثهر. } \\
& \text { الاستتتاجات: استخدام موجه القند المشيمي البشري يؤدي الى تجمع للافر ازات داخل البروستات وبالتالي يؤثر على لئى } \\
& \text { تركيب البروستات. }
\end{aligned}
$$

$\mathrm{H}$

uman chorionic gonadotropin

(hCG) is a placental glycoprotein hormone with pharmacological actions virtually identical to those of luteinizing hormone $(\mathrm{LH})^{1}$. This hormone can be extracted from the urine of pregnant females and its preparations are widely used as therapeutic agents by both sexes. In males, its administration is accompanied by an increase in libido, improvement of sexual performance and elevation of sperm count ${ }^{2}$. Whereas, in females hCG administration is associated with a favorable outcome during ovarian stimulation, since higher pregnancy rates occurred in cycles in which hCG was given ${ }^{3}$.

In addition to its many therapeutic uses, this hormone is frequently abused by many people across the world unaware of the hidden side effects associated with it. With the recent introduction of several newer commercial forms of hCG, there is an escalating abuse of this drug. Besides the injectable form, hCG products are available as sublingual drops, lozenges, and pellets, but none of these forms has an evidence-based efficacy and safety standard ${ }^{4}$. Furthermore, these forms are simple and easy to administer by the abusers without any pain. Authors demonstrated that the use of hCG preparations is associated with many side effects. Though, data concerning the histological and histochemical effects on the prostate are very deficient.

\section{Aims of the study}

This experimental study was designed to evaluate the histological and histochemical effects of different therapeutic doses of hCG on the prostate of adult albino rats, and to assess the reversibility of the changes at one month intervals from cessation of the therapy for another three months. Serum levels of testosterone were verified to correlate the induced changes with the hormone values.

\section{Materials and methods}

Eighty healthy adult male albino rats of Wistar strain were divided randomly into 4 groups of 20 animals each; 3 treated groups $\mathrm{A}, \mathrm{B}$, and $\mathrm{C}$, while the fourth group was served as a control. The rats were housed in polypropylene cages $(55 \times 37 \times 15 \mathrm{~cm})$ with stainless steel top grill, in groups of 10 rats per cage, for the period from $1^{\text {st }}$ of January till the end of June 2013. A number of female rats were reserved with them to maintain their normal sexual activities. The animals were maintained in a well ventilated, air conditioned room under natural conditions of approximately 12 hours light and dark cycle, and a temperature of about $25 \pm 2{ }^{\circ} \mathrm{C}$. During the whole period, the animals had access to tap water and were fed with commercially prepared food ad libitum.

The treated groups (A, B and C) were received 10,50 or $100 \mathrm{IU} / \mathrm{kg} \mathrm{BW}$ of hCG respectively, whereas the control 
group received equal amounts of normal saline. The doses were given twice weekly for 3 months via subcutaneous injections (total 24 doses). Subsequently, on day 1, 30, 60 and 90 post therapy, 5 rats from each group were anesthetized, blood samples were collected for hormonal assay, and finally the animals were euthanized and sacrificed to obtain the prostate glands for evaluation.

Serum testosterone levels were determined using luminescence technology in combination with magnetic micro particles (LIAISON). The hormone assay was run in the same laboratory to eliminate any difference in the results. The values of the control group were considered as standard, and they were compared with the results obtained from the different treated groups.

The prostate glands were fixed in $10 \%$ neutral buffered formalin. Sequentially, the processed sections were stained with Hematoxylin and Eosin (H\&E), Periodic acid-Schiff (PAS) and Van-Gieson's (VG). The stained sections of the control and the treated groups were studied thoroughly under light microscope (Olympus, Tokyo, Japan). And they were analyzed quantitatively using visopan projection microscope (Reichert, Austria).

Numerical data obtained from each group were expressed as mean \pm standard deviation (SD). Statistical significance of the data was determined using Student's $t$ test. Comparisons of data from different groups were evaluated by ANOVA. p values less than 0.05 were considered statistically significant.

\section{Results}

Human chorionic gonadotropin therapy resulted in a marked elevation of the serum testosterone. The alteration of the hormone level was dose dependent. On the other hand, the magnitude of the effects of hCG appear to be dose limited; all data showed no any statistically significant difference between those received 50 or $100 \quad \mathrm{IU} / \mathrm{kg} \quad \mathrm{BW}$. Successive evaluation of serum hormone level manifested sensible and continuous improvement of its values, with a complete recovery by the end of second month post therapy (figure 1).

The rat prostate gland was composed of ventral and two dorsolaleral lobes. The acini of the dorsolateral lobes showed more mucosal folds, whereas they were fewer in acini of the ventral lobe. The lining epithelium of the acini was simple columnar with basophilic cytoplasm and basal nuclei, resting on regular intact basement membrane. Most of the acini were filled with the eosinophilic secretory material.

The histological response of the prostate to the therapy was similar in all the different treated groups. Immediately after the treatment, the acini of the ventral and the dorsolateral lobes were increased in size and filled with eosinophilic secretory material. The acini of the ventral lobe revealed either disappearance of the mucosal folds, or they were very few and shallow (figure 2). Furthermore, epithelial metaplasia of the ventral acinar cells was one of the most common findings; the lining epithelium of the acini showed variable degrees of transformation in its height, it was either tall columnar similar to that of the controls, short columnar, cuboidal, or even flat squamous epithelium. On the other hand, the acini of the dorsolateral lobes showed lesser degree 
of alteration; they still exhibited many mucosal folds, lined with tall or short columnar epithelial cells. The acini of both the ventral and the dorsolateral lobes exhibited epithelial hyperplasia, which was another prominent finding. It was identified either as foci of multilayered epithelium, or in more advanced stages they appeared as foci crowded with epithelial cells and projected into the lumen of the acini (figure 3).

This picture continued for the first month following the therapy. Subsequently, by the end of the second month, majority of the acini of the ventral and the dorsolateral lobes appeared relatively normal in size. The mucosal folds of the ventral lobe acini started to reappear, these acini were lined with tall or short columnar epithelial cells. However, the acini of the dorsolateral lobes appeared normal at this period of time; they revealed many mucosal folds and were lined with tall columnar epithelial cells. In both lobes, few foci of epithelial hyperplasia were still persisted, particularly in the ventral lobe. By the end of the third month following the therapy, the mucosal folds of the ventral lobe were essentially normal. All the acini were lined with tall columnar epithelial cells and contained eosinophilic secretory material. However, infrequent scattered foci of epithelial hyperplasia were still observed in the acini of the ventral lobe.

The therapy didn't alter the distribution of the PAS +ve material of the prostate glands. Intense PAS reactions were detected in the basement membranes, as well as the acinar epithelial cells particularly in their luminal border and apical cytoplasm. Slightly weaker reactions were observed in the connective tissue stroma (figure $4)$.

As regards the collagen fibers, on day 1 post therapy there was noticeable increase in the collagen fiber content of the prostate in the treated groups (figure $5)$. This density persisted till the end of first month. By the end of the second month, the gland still revealed milder degree of increase in the collagen fiber content. Eventually, by the end of the third month, the density of the collagen fibers was nearly similar to that of the controls. 
Iraq J Pharm

Vol. 15, No.1, 2018

Table 1: Parameters of the prostate gland

\begin{tabular}{|c|c|c|c|c|c|}
\hline \multirow[b]{2}{*}{ Group } & \multirow[b]{2}{*}{ Period } & \multicolumn{2}{|c|}{ Ventral lobe } & \multicolumn{2}{|c|}{ Dorsolateral lobe } \\
\hline & & $\begin{array}{l}\text { Diameter of } \\
\text { acini }(\mu \mathrm{m})\end{array}$ & $\begin{array}{l}\text { Height of } \\
\text { epithelium } \\
(\mu \mathrm{m})\end{array}$ & $\begin{array}{c}\text { Diameter of acini } \\
(\mu \mathrm{m})\end{array}$ & $\begin{array}{c}\text { Height of } \\
\text { epithelium } \\
(\mu \mathrm{m})\end{array}$ \\
\hline Control & All periods & $671 \pm 56.52$ & $16.2 \pm 2.44$ & $387.6 \pm 44.85$ & $16.4 \pm 2.74$ \\
\hline \multirow{4}{*}{$\mathbf{A}$} & Day 1 & $862 \pm 49.41^{*}$ & $10.6 \pm 2.20^{* *}$ & $533 \pm 39.76^{*}$ & $13.7 \pm 3.12^{* *}$ \\
\hline & Day 30 & $798.4 \pm 50.83^{*}$ & $12.2 \pm 1.90^{*}$ & $430 \pm 40.71^{*}$ & $14.3 \pm 2.10^{*}$ \\
\hline & Day 60 & $710 \pm 53.40$ & $15.5 \pm 2.11$ & $400 \pm 37.82$ & $16.1 \pm 2.05$ \\
\hline & Day 90 & $690.5 \pm 34.98$ & $16.1 \pm 2.01$ & $378 \pm 30.09$ & $16.3 \pm 2.28$ \\
\hline \multirow{4}{*}{ B } & Day 1 & $982 \pm 55.86^{*}$ & $10.3 \pm 1.88^{* *}$ & $552 \pm 40.33^{*}$ & $12.9 \pm 1.96^{* *}$ \\
\hline & Day 30 & $967.6 \pm 38.62^{*}$ & $11.9 \pm 1.54^{*}$ & $480 \pm 57.48^{*}$ & $14.1 \pm 2.12^{*}$ \\
\hline & Day 60 & $751.5 \pm 58.44$ & $15.2 \pm 1.98$ & $406 \pm 15.85$ & $16.1 \pm 1.06$ \\
\hline & Day 90 & $710 \pm 44.09$ & $16 \pm .1 .76$ & $400 \pm 31.90$ & $16.3 \pm 3.10$ \\
\hline \multirow{4}{*}{$\mathbf{C}$} & Day 1 & $986 \pm 36.41^{*}$ & $10.1 \pm 1.23^{* *}$ & $579 \pm 30.63^{*}$ & $12.8 \pm 2.27^{* *}$ \\
\hline & Day 30 & $958.7 \pm 40.75^{*}$ & $11.5 \pm 1.11^{*}$ & $502 \pm 39.94^{*}$ & $14 \pm 1.97^{*}$ \\
\hline & Day 60 & $770.5 \pm 43.10$ & $15.1 \pm 2.02$ & $411 \pm 20.19$ & $15.9 \pm 2.21$ \\
\hline & Day 90 & $705 \pm 47.96$ & $16 \pm 2.11$ & $385 \pm 28.08$ & $16.2 \pm 2.89$ \\
\hline
\end{tabular}

Data are expressed as mean $\pm \mathrm{SD}$

*Values of significant difference at $p<0.05$

${ }^{* *}$ Values of significant difference at $p<0.005$

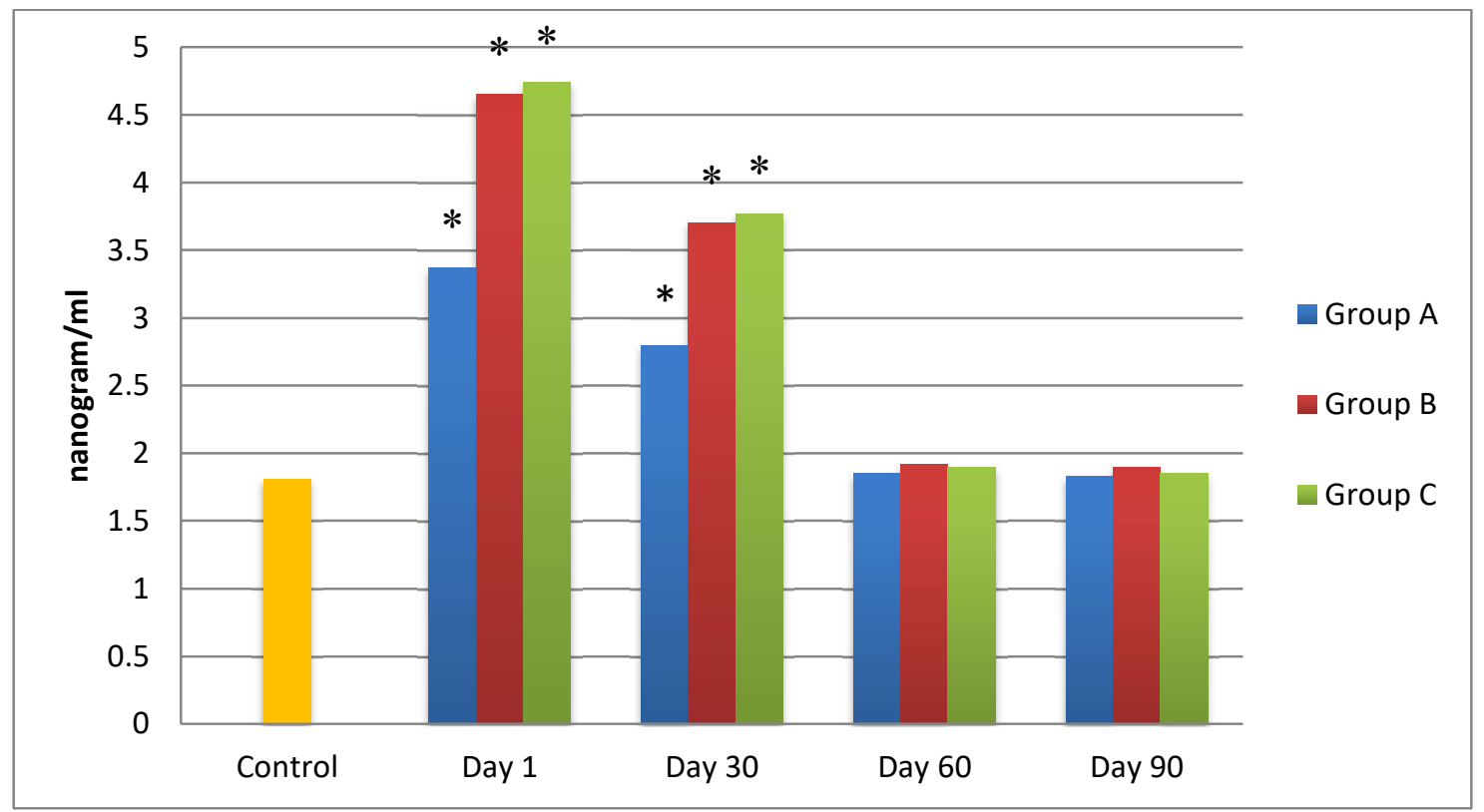

Figure 1: Effect of hCG therapy on the mean serum level of testosterone. Means are significant at $p<0.05$

* Values of significant difference at $p<0.001$ 


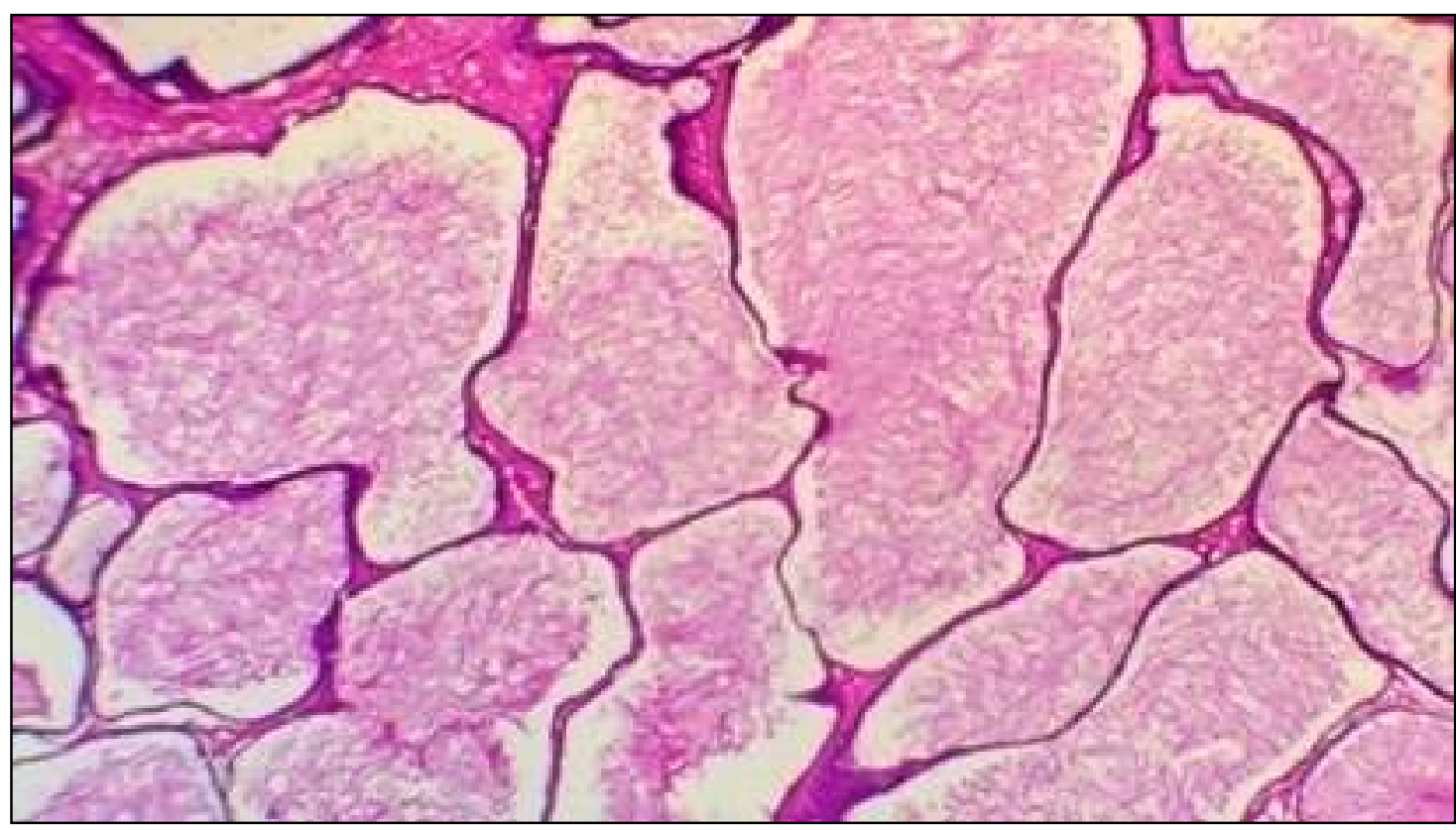

Figure 2: Micrograph of a section in the prostate of a rat from group A, on day 1 post treatment, showing dilated acini of the ventral lobe without mucosal folds, filled with eosinophilic secretory material, (H\&E x40).

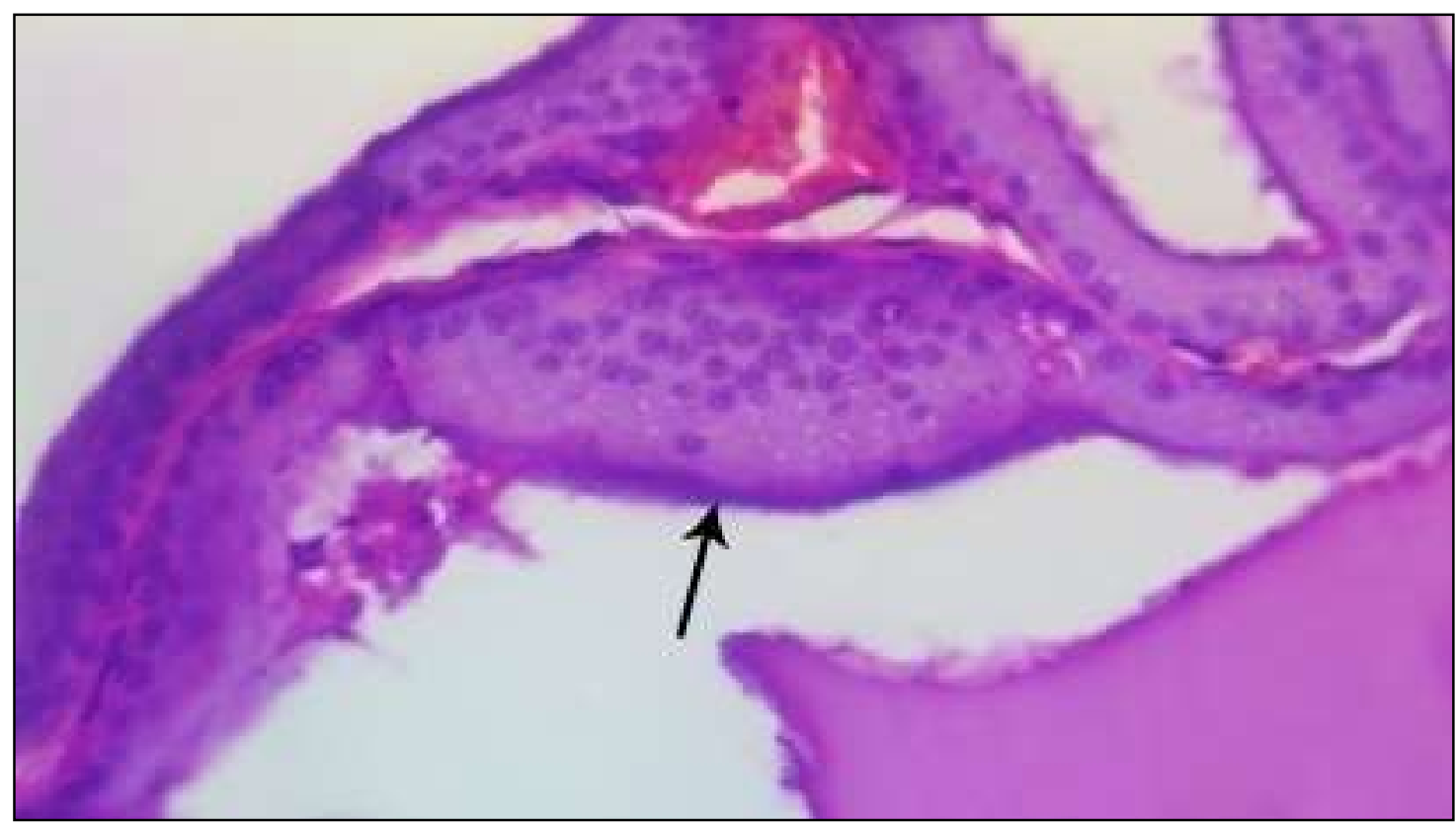

Figure 3: Micrograph of a section in the prostate of a rat from group A, on day 1 post treatment, showing focus crowded with epithelial cells and projected into the lumen of an acinus (arrow), (H\&Ex400). 


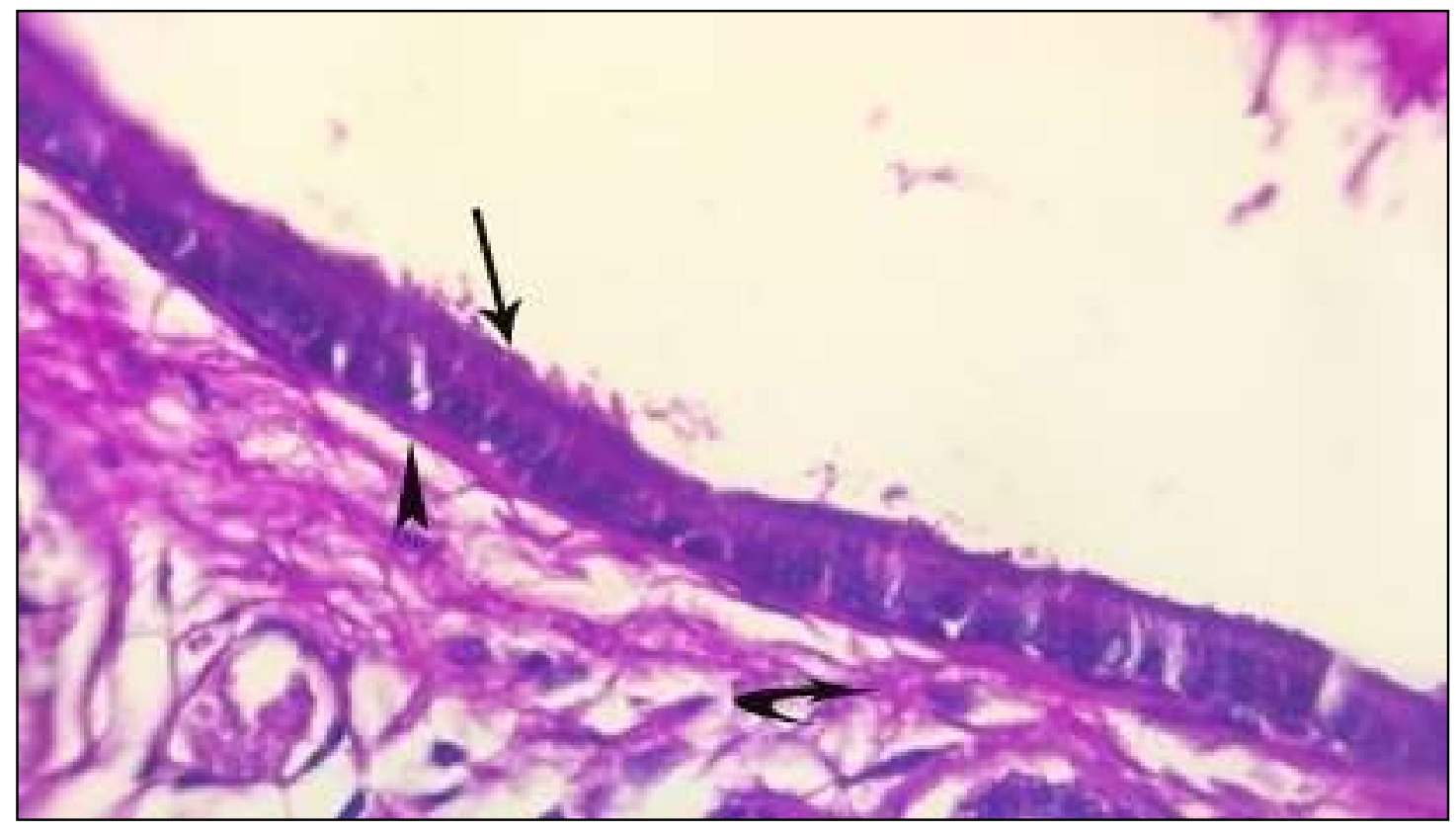

Figure 4: Micrograph of a section in the prostate of a control rat, showing intense PAS reaction in the epithelium (arrow), and the basement membrane (arrowhead). While slightly weaker reaction in the connective tissue stroma (curved arrow), (PAS x400).

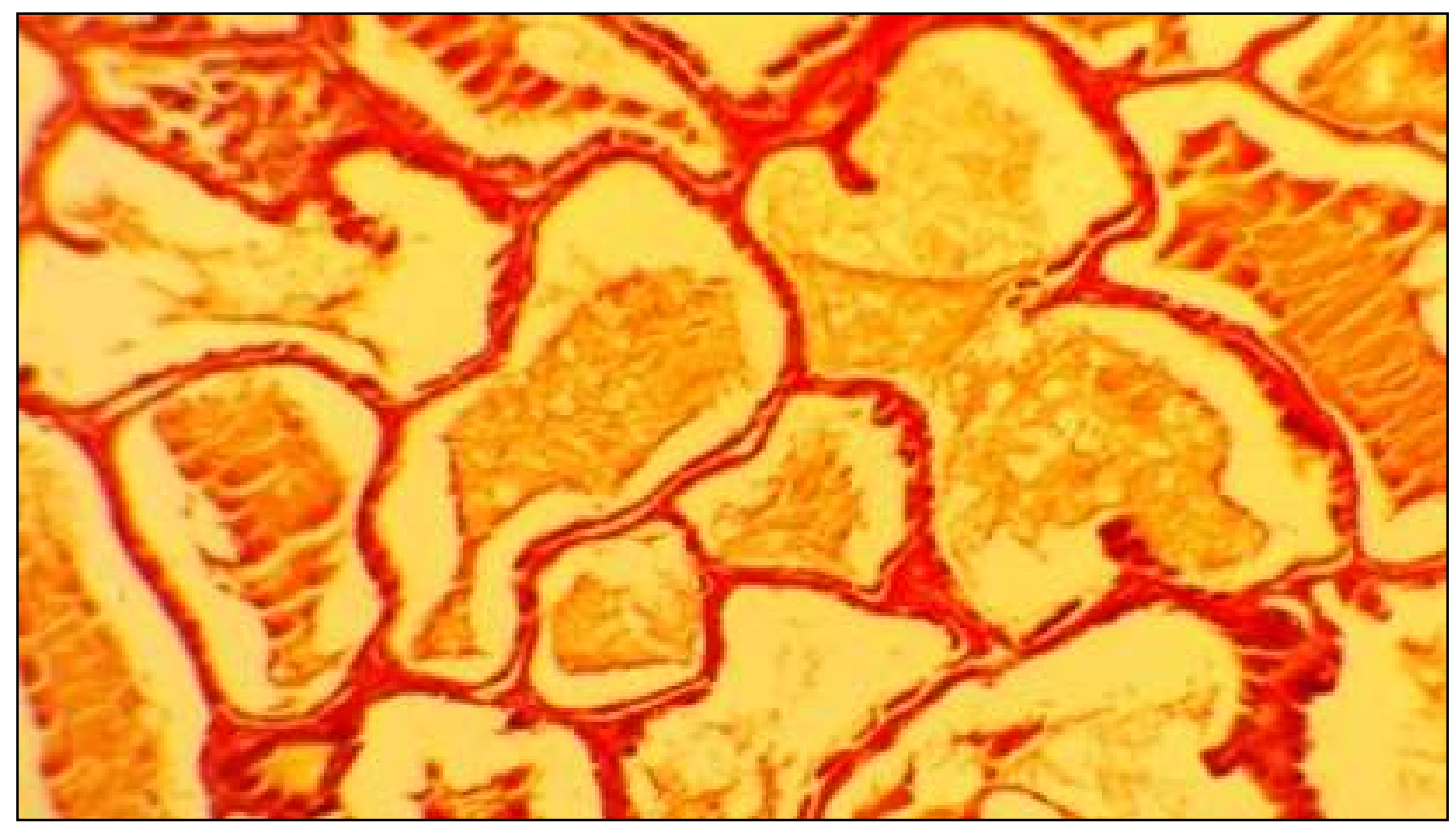

Figure 5: Micrograph of a section in the prostate of a rat from group B, on day 1 post treatment, showing increase in the collagen fiber content (red in color), $(V G \times 40)$. 


\section{Discussion}

The results of the present study are in agreement with the findings of Susana et al. $(2003)^{5}$ who reported similar changes in prostate of transgenic mice overexpressing $\mathrm{hCG}$ with high androgen level. Several studies have demonstrated that the prostate is androgen dependent glands ${ }^{6,7}$. Researches demonstrated rudimentary accessory sex organs in luteinizing hormone/choriogonadotropin receptors (LHCGR) knockout mice, which were recovered after testosterone replacement ${ }^{8}$. Other works confirmed that androgen ablation in adulthood promotes a fast and extensive involution of the prostate with arrest of their secretory activity and elimination of epithelial cells by apoptosis ${ }^{9,10}$. The fast collapse of glandular parenchyma is followed by a slower stromal atrophy ${ }^{11}$. Furthermore, testosterone replacement restores the original architecture of the gland $^{12}$.

Current data revealed dilatation of the glandular lumens of the prostate glands. This dilatation is either due to the increased secretory activity of the gland induced by the high testosterone levels ${ }^{13}$, or because of impaired emptying of the gland. Susana et al. $(2003)^{5} \quad$ suggested a functional infravesical urethral obstruction in transgenic male mice over-expressing hCG with high androgen level. The reduction in the height of the lining epithelial cells observed in the prostate could be attributed to the mechanical pressure. Two factors are suggested to cause this pressure: firstly, the large amount of the secretory materials, and secondly the increased density of the collagen fibers in the stroma which restrict the distension of the glandular lumens. A similar phenomenon has been reported by
Anthony et al. (1982) ${ }^{13}$ who demonstrated pressure atrophy of the pancreatic acinar cells caused by obstruction of the terminal intercalated ducts. Moreover, the suggested increased pressure in the glandular lumens compressed the mucosal folds and resulted in diminution or disappearance of these folds.

Acosta et al. (2004) $)^{14}$ described epithelial hyperplasia in guinea pig prostate after long term testosterone stimulation. In addition, Lourdes et al. (2007) ${ }^{15}$; Shan et al. (2010) ${ }^{16}$; Young et al. $(2012)^{17}$ used exogenous testosterone injections to induce prostatic hyperplasia in rats in order to study the efficacy of other drugs which are currently used in treatment of benign prostatic hyperplasia in men. Furthermore, Gat et al. $(2008)^{18}$ stated that testosterone is the promoter of prostate cell proliferation. Therefore, the prostatic epithelial hyperplasia identified in this study could be attributed to the high testosterone level achieved by hCG therapy.

The presence of increased amount of collagen fibers in the stroma of the prostate is possibly due to either hormonal or non hormonal mechanisms. According to the hormonal mechanism, the stimulatory effect of testosterone increases the biosynthesis of collagen from fibroblast. This mechanism is supported by findings of Srinivasan et al. $(1986)^{19}$; Kim and Chai $(1987)^{20}$ who noticed that low androgen level induced by castration decreases the collagen content of the rat prostate, whereas testosterone administration prevents this reduction. On the other hand, non hormonal mechanism might predispose to this increase in the collagen fibers; the distension of the glandular lumens by the secretory material might exert pressure on the adjacent stroma and subsequently 
tissue hypoxia occurred due to compression of the blood vessels which promote formation of collagen fibers as suggested by Falanga et al. (2002) ${ }^{21}$; Horino et al. $(2002)^{22}$; Hofbauer et al. $(2003)^{23}$

Following cessation of hCG therapy, the stepwise recovery of the serum testosterone level was associated with gradual improvement of the qualitative and the quantitative histological alterations in the prostate. These findings support the earlier suggestion that the elevated testosterone was responsible for these changes.

\section{Conclusions}

Treatment with different doses of hCG causes accumulation of large amount of the secretory products within the glandular lumens of the prostate, results in dilatation of its lumens, as well as reduction of the height of both the mucosal folds and the lining epithelial cells. hCG administration induces epithelial hyperplasia of the prostate. This therapy also causes increase in the collagen fibers of the gland, but does not alter the general distribution of the PAS +ve material. Most of these changes are reversible within 3 months.

\section{References}

1. Anne Cailleux-Bounacer, Yves Reznik, Bruno Cauliez, et al. Evaluation of endocrine testing of Leydig cell function using extractive and recombinant human chorionic gonadotropin and different doses of recombinant human LH in normal men. European Journal of Endocrinology 2008; 159: 171-78.

2. Mazhar Mushtaq, Saghir Ahmed, Abdus Salam, et al. Human
Chorionic Gonadotropin (hCG): A treatment of oligospermia. Pak J Med Sci 2007; 23(6): 840-46.

3. Mohamed F Mitwally, Sonya AbdelRazeq and Robert F Casper. Human chorionic gonadotropin administration is associated with high pregnancy rates during ovarian stimulation and timed intercourse or intrauterine insemination. Reproductive Biology and Endocrinology 2004; 2:55.

4. Goodbar NH, Foushee JA, Eagerton $\mathrm{DH}$, et al. Effect of the human chorionic gonadotropin diet on patient outcomes. Annals of Pharmacotherapy 2013; 47(5): 23.

5. Susana B Rulli, Petteri Ahtiainen, Sari Ma Kella, et al. Elevated steroidogenesis, defective reproductive organs, and infertility in transgenic male mice overexpressing human chorionic gonadotropin. Endocrinology 2003; 144(11): 4980-90.

6. Hayward SW, Baskin LS, Haughney PC, et al. Stromal development in the ventral prostate, anterior prostate and seminal vesicle of the rat. Acta Anatomica 1996; 155(2): 94-103.

7. Sastry MS and Sushmita Choudhury. Histochemical changes in Leydig cells and seminiferous tubules of microchiropteran bat hipposideros speoris during testicular cycle. The Bioscan 2011; 6(4): 681-84.

8. Pakarainen T, Zhang FP, Makela S, et al. Testosterone replacement therapy induces spermatogenesis and partially restores fertility in luteinizing hormone receptor knockout mice. Endocrinology 2005; 146: 596-606.

9. Aoki MP, Maldonado CA and Aoki. A Apoptotic and non-apoptotic cell 
death in hormone-dependent glands. Cell Tissue Res 1998; 291: 571-74.

10. $\mathrm{Hu} \mathrm{Z}$, Ito $\mathrm{T}$, Yuri $\mathrm{K}$, et al. In vivo time course of morphological changes and DNA degradation during the degeneration of castration-induced apoptotic prostate cells. Cell Tissue Res 1998; 294: 153-60.

11. Vilamaior PS, Felisbino SL, Taboga $\mathrm{SR}$, et al. Collagen fiber reorganization in the rat ventral prostate following androgen deprivation: a possible role for smooth muscle cells. Prostate; 2000: 45: 253-58.

12. Luis A Justulin Jr, Rodrigo $\mathrm{P}$ Ureshino, Michelle Zanoni, et al. Differential proliferative response of the ventral prostate and seminal vesicle to testosterone replacement. Cell Biology International 2006; 30: 354-64.

13. Anthony SYL, Slavotinek AH, Deakin EJ, et al. The pathology of experimental chronic flbroslng pancreatitis-light microscopic and ultrastructural observations. Pathology 1982; 14(4): 363-68.

14. Acosta S, Dizeyi N, Feinstein R, et al. Long-term testosterone stimulation induces hyperplasia in the guinea-pig prostate. Prostate Cancer and Prostatic Diseases 2004; 7: 227-31.

15. Lourdes de AM, Molina V, Mas R, et al. Effects of coconut oil on testosterone-induced prostatic hyperplasia in Sprague-Dawley rats. J Pharm Pharmacol 2007; 59(7): 995-99.

16. Shan HL, Hye JR, Eun SP, et al. Vitamin $\mathrm{C}$ supplementation prevents testosterone-induced hyperplasia of rat prostate by down regulating HIF-
1 $\alpha$. J Nutritional Biochemistry 2010; 21(9): 801-808.

17. Young ML, Shin IS, Hun NL, Hyekyung $\mathrm{H}$, et al. Effects of Platycodon grandiflorum methanolic extract on testosterone-induced benign prostatic hyperplasia in Wistar rats. African Journal of Biotechnology 2012; 11(77): 1418692.

18. Gat Y, Gornish M, Heiblum M, et al. Reversal of benign prostate hyperplasia by selective occlusion of impaired venous drainage in the male reproductive system: novel mechanism, new treatment. Andrologia 2008; 40(5): 273-81.

19. Srinivasan N, Aruldhas $M M$ and Govindarajulu P. Sex steroidinduced changes in collagen of the prostate and seminal vesicle of rats. J Androl 1986; 7(1): 55-58.

20. Kim JH and Chai SE. Effects of Sex Hormones on collagen levels in male accessory sex organs of rats. Korean J Urol 1987; 28(4): 479-87.

21. Falanga V, Zhou L and Yufit T. Low oxygen tension stimulates collagen synthesis and COL1A1 transcription through the action of TGF-beta1. J Cell Physiol 2002; 191: 42-50.

22. Horino Y, Takahashi S, Miura T, et al. Prolonged hypoxia accelerates the posttranscriptional process of collagen synthesis in cultured fibroblasts. Life Sciences 2002; 71: 3031-45.

23. Hofbauer KH, Gess B, Lohaus C, et al. Oxygen tension regulates the expression of a group of procollagen hydroxylases. Eur J Biochem 2003; 270: 4515-22. 